Vol. 6(6), pp. 200-204, J une 2014

DOI: $10.5897 /$ J ENE10.081

Artic le Number. 60633D645305

ISSN 2006-9847

Copyright (C) 2014

Author(s) retain the copyright of this article

http:// www.academic joumals.org/J ENE

\section{Journal of Ecology and the Natural Environment}

\title{
Land degradation assessment of agrarian soils in Ebonyin State for sustainable production
}

\author{
Ande O. $\mathrm{T}^{1^{*}}$. and Senjobi B. $\mathrm{A}^{2}$. \\ ${ }^{1}$ Institute of Agriculture Research and Training, OAU, Moor Plantation, Ibadan, Oyo State, Nigeria. \\ ${ }^{2}$ University of Agriculture, Abeokuta, Ogun State, Nigeria.
}

Received 20 October 2010; Accepted 19 May, 2011

\begin{abstract}
The experiment was conducted to assess land degradation in agrarian soils of Ebonyin State. Ten farmers' fields were selected based on land use and landscape positions across the three zones in the state. Physical and socio- economic information were obtained from the farmers and extension agents. Surface and sub-surface soil samples were collected for physical and chemical analysis. The soils at the upland were clay loam and at lower slope to valley bottom were clay loam to clay in texture. The upland and low land soils were strongly acidic (4.1) to moderately acidic (5.5) with low P (3.36 - 5 $\mathrm{mg} / \mathrm{kg}$ ). The soils also were low in cation exchange capacity (CEC) $(1.36$ - 2.68). Soil degradation indicators include crop conditions, poor yield, low fertility level, shallow soil depth $(50 \mathrm{~cm})$, high gravel content (>35\%), compaction of exposed sub soils and soil erosion. The factors and causes of soil degradation include improper tillage system, continuous cultivation, nutrient mining due to many crops per heap under mixed cropping and improper crop combination. Conservation agriculture with minimum tillage and green manure are recommended for sustainable production while combination of organic and in-organic fertilizer is recommended to improve soil quality.
\end{abstract}

Key words: Land use, soil degradation indicators, tillage systems, cropping systems and poor yield.

\section{INTRODUCTION}

Land degradation will remain an important global issue for the $21^{\text {st }}$ century because of its adverse impact in agronomic productivity, environment, food security and quality of life. The existing technology have invited host of problems of production declining land quality and degradation of soils of the areas. The productivity of some soil had decline by $50 \%$ due to erosion and desertification (Pagiola, 2002). Yield reduction in Africa due to past soil erosion ranges from 2 - 4\%. In Asia, annual loss in productivity is estimated at 36 milliontonnes of cereals. Land degradation is a decline in soil qualities, which can be considered in term of issue of actual or potential productivity or utility as a result of natural or autotrophic factors (Beinroth et al., 1994).

Land clearing, agricultural depletion of soil available nutrients status/immobilization, irrigation, pollution, accelerated erosion by wind or rain acidification or alkalinezation, salinization destruction of soil structures through the loss of soil organic matter are prevalent causes and processes that easily result to land degradation in Nigeria. Soil compaction hard crusting is a worldwide problem, especially with adoption of mechanized agriculture.

*Corresponding author. E-mail: funmiande@yahoo.com.

Author(s) agree that this article remain permanently open access under the terms of the Creative Commons Attribution License 4.0 International License 
It has caused yield reduction of $25-50 \%$ in some regions of Europe (Erickson, 1999) and between 40 - 90\% in West Africa (Lal, 1994). Nutrient depletion as a form of land degradation has severe Economic impact at the global scale, especially in sub-Sahara African. Annual depletion rate of soil fertility was estimated as $25 \mathrm{kgN} / \mathrm{ha}$, $3 \mathrm{kgP} / \mathrm{ha}$ and $15 \mathrm{kgK} / \mathrm{ha}$ (Nyathi et al., 2003).

Soil fertility decline refers to deterioration in soil, the physical and chemical, biological properties, by reduction in soil organic status leads to decline in soil biological activities. Degradation in soil physical properties structure, aeration, water holding capacity caused by reduced organic matter, adverse change in soil nutrient status including reduction in availability of major nutrients (NPK), initiation of the micro nutrient deficiencies and development of nutrient imbalance.

Land degradation is a reduction or loss of biological economic productivities of crops and or range pasture, forest wood land resulting from land use or from processes of soil erosion caused by wind results in and results in deterioration of the physical, chemical and biological economic properties of soil and long terms loss of natural vegetation (Evenson and Gollin, 2003).

There are certain indicator of degradation that can be assessed in different land use pattern (Worden et al., 2003). indicators include change in hydrologic regimes in a forest by the use of epiphyte such as mosses and bryophytes; change in soil reaction (acidity and alkalinity) due to the salinization or acidification; change in nutrient status of the soil such as fertile or poor soil; crop yield data ( Table 1b) and plant conditions during the growth stage.

\section{MATERIALS AND METHODS}

Field study was conducted on selected farmers' field based on their cropping system and terrain characteristic. The selected sites were characterized and relevant data on soils, its climatic, crop production problems and history, landscape and yield were collected. Soil samples were collected in three replicates from surface and subsurface from plots of $5 \times 5 \mathrm{~m}$ marked on the farmers' field. The samples were processed for physical and chemical analysis.

The results were interpreted to determine factors of land degradation and appropriate intervention for sustainable land use; the physical and chemical analysis carried out on the soil samples. Particle size analysis was done using Bouyocos (1999) method, bulk density was determined by core method. Cations were extracted by using $\mathrm{NH}_{4} \mathrm{OAC}$ (Ammonium Acetate) $\mathrm{Ca}$ and $\mathrm{Mg}$ were read with atomic absorption spectrophotometer $\mathrm{Na}^{+}$and $\mathrm{K}^{+}$by flame photometer. Walkley black method was used for organic carbon determination.

Phosphorus was determined using Bray1 method. The cation exchange capacity (CEC) was calculated by sum of bases. Nitrogen value was derived from organic carbon content.

\section{Land degradation assessment by direct approach}

Random on each farm land use were placed in degradation classes by soil characteristics with the land indicators (Tables 4 and 5). Classification was done following the approach of FAO (1979) and
Snakin et al (1996). The estimation of degree of degradation was based on physical, chemical and biological properties of soil and parameters of land use types at location were studied. The soils were ranked based on degree of degradation.

\section{RESULTS AND DISCUSSION}

\section{Landscape, land use and cropping systems}

The study areas is characterised by undulating to rolling landscape. Sites were located at different positions on the landscape from upland to valley bottoms. The upland soils were used for cassava, maize, potato, yam and vegetables activation. While the valley bottom soil were reserved for rice cultivation (Table 1).

Mixed cropping is the usual practice at the upland while mono-cropping of rice is the practice at the lower slope. The upland soils are usually cultivated intensively for four years before being left for fallow while rice is usually cultivated continuously. Agro-forestry is practiced close to homestead.

The average soil depth on the farm was about $50 \mathrm{~cm}$ with laterite in the sub-soil. The rainfall ranges between 1000 to $12000 \mathrm{~mm}$ per annum.

\section{Physical and chemical properties}

The data of physical and chemical analysis of the surface and sub surface soils were indicated that (Tables 2, 3) the soils were having high clay content which ranged between 31.2 to $56.2 \%$ in both upland and valley bottom soils with an average soil depth about $50 \mathrm{~cm}$.

The chemical analysis of soil sample showed that the soils were strong acidic ( $\mathrm{pH} 4.1)$ to moderate acidic $\mathrm{pH}$ 5.5 with low $P$ content (3.36-5.44 $\mathrm{mg} / \mathrm{kg}$ soil). CEC ranged between $1.25-2.68 \mathrm{cmol} / \mathrm{kg}$ soil which could have resulted in poor yield of the crops in the area. Higher CEC $6.252-8.92 \mathrm{cmol} / \mathrm{kg}$ was recorded form surface to sub surface in agro forest areas.

The soil fertility is usually maintained by shifting cultivation and application of fertilizer. However soils under fallow period of 2 to 3 years were also found to be in low fertility. This indicates that the fallow period is too short to build up soil fertility (Table 2).

Interaction with farmers showed that one bag fertilizer (NPK 15:15:15) per acre was the usual practice. This is below the crop requirement on low fertility soils for profitable production. The data on land degradation indicators (Table 4) shows that $60 \%$ of the studied area was highly degraded. $90 \%$ of the area was highly deficient in N, 50\% soils were moderate to highly deficient in $\mathrm{P}, 60 \%$ was moderately degraded in K. $60 \%$ of the area was found to be slightly degraded in organic matter while $20 \%$ of the soils was very low in organic matter content. Bulk density of the soils ranged between 1.10 to1.60 which resulted to $60 \%$ highly degraded and $40 \%$ moderately degraded. 
Table 1. On-farm land degradation assessment in Ebonyin State.

\begin{tabular}{|c|c|c|c|}
\hline Landscape position & $\begin{array}{l}\text { Land use/Cropping } \\
\text { system }\end{array}$ & Degradation indicator & Management levels \\
\hline Valley bottom & Rice (sole) & $\begin{array}{l}\text { Small panicles, stunted growth, ferric } \\
\text { solution. }\end{array}$ & Medium \\
\hline Upland & $\begin{array}{l}\text { (Mono-cropping) } \\
\text { Yam /cassava / okra }\end{array}$ & $\begin{array}{l}\text { Thin stems, Leaf chlorosis, stunted growth, } \\
\text { small tubers gravel soils }\end{array}$ & Medium \\
\hline Upland & Agro-forestry & Soil colour & Low \\
\hline Upland & Maize/yam/cassava & Sub surface Soil compaction, gravel soil & Medium \\
\hline Upland & Fallow & Grasses & Medium \\
\hline Lowland/valley bottom & $\begin{array}{l}\text { Rice (Mono- } \\
\text { cropping) }\end{array}$ & Small panicles, stunted growth & Medium \\
\hline Lowland/valley bottom & $\begin{array}{l}\text { Yam/cassava /Okra } \\
\text { rice sole. }\end{array}$ & Ferric solution, iron toxicity & Medium \\
\hline Upland & $\begin{array}{l}\text { Yam, cassava, } \\
\text { potato, okra }\end{array}$ & $\begin{array}{l}\text { Thin stems, small tubers, low yield, } \\
\text { gravel/plinthile }\end{array}$ & Medium \\
\hline Fallow & - & Grasses & Medium \\
\hline Lowland & $\begin{array}{l}\text { Maize, } \\
\text { potato }\end{array}$ & Low yield & Medium \\
\hline
\end{tabular}

Table 1b. Average crop yield in Ebonyin State

\begin{tabular}{cllc}
\hline Location & Land use & Cropping system & Yield (t/ha) \\
\hline 1 & Rice & Sole & 1.5 \\
2 & Cassava & Mixed cropping & 5.0 \\
3 & Cassava & Mixed cropping & 5.0 \\
4 & Maize & Mixed cropping & 1.6 \\
5 & Rice & Sole & 1.5 \\
6 & Rice & Sole & 1.5 \\
7 & maize & Mixed cropping & 1.8 \\
\hline
\end{tabular}

\section{Land degradation indicators: Soil fertility, cropping system and tillage methods}

The continuous production on soils for over two decades without sufficient fertilization and manuring has resulted in low soil fertility status of the soils. Shallow soil depth and tillage practices have also contributed to soil degradation. The usual traditional method of tillage involves making large heaps by scraping surface soils to about 50 $\mathrm{cm}$ depth. This practice has resulted to exposure of sub soils, formation of large furrows aiding erosion activities and sub surface hard crusting. Ridges were made along in the area creating channels for soil erosion. This has been attributed to accelerated soil erosion with consequent loss of top soils in the area. The over utilization of lands under mixed cropping was also observed as one of land degrading factors. Similar observation was made by Michael and Niamh (2000). Improper root crops combina- tion (such as cassava/yam/potato mixtures) with 5 to 10 cassava plants on a heap and other crops such as maize and okro is the usual practice. Hence unhealthy competition for scarce soil nutrient is inevitable. Evidence of Iron toxicity was also observed on the fields with leave chlorosis, small panicles and low yield on rice farms. These observations were reported as evidence of iron toxicity by Mathias and Folkard (2005). The valley bottoms area were highly acidic. This could be attributed to high organic waste with slow rate of decomposition due to hydromorphic condition prevailing in such locations. This has been reported to cause immobilization of available nutrients and less availability of plant nutrients specially those nutrients which are soluble under high soil pH such as $\mathrm{P}$ and $\mathrm{K}$ (Mathias and Folkard (2005).

\section{Management methods}

Management practices such as burning of farm bye products and planting of arable crops with tree crops without adequate spacing are also contributing factors to soil fertility decline. In order to improve the soil quality, organic fertilizer or organic fertilizer fortified with inorganic fertilizers, suitable cropping system/combinations are recommended. Controlled fallow (Ande and Onajobi, 2009) which involve use of crops that produce high bio-mass rapidly should be included in the fallow such as Mucuna, Mexican sunflower and Chromolaena odorata. Audebert and Saahrawat (1996) observed that inclusion of legumes at the upland position above valley bottoms was capable 
Table 2. Mean values of surface physical and chemical properties of soil from major cropping system

\begin{tabular}{|c|c|c|c|c|c|c|c|c|c|c|c|c|c|c|c|c|c|}
\hline \multirow{2}{*}{ Land use } & \multirow{2}{*}{$\begin{array}{c}\text { Sand } \\
(\%)\end{array}$} & \multirow{2}{*}{$\begin{array}{l}\text { Silt } \\
(\%)\end{array}$} & \multirow{2}{*}{$\begin{array}{c}\text { Clay } \\
(\%)\end{array}$} & \multirow{2}{*}{ Texture } & \multirow{2}{*}{$\begin{array}{c}\text { BD } \\
\mathbf{g c m}^{3} \\
\end{array}$} & \multirow{2}{*}{ pH } & $\mathrm{Ca}$ & Mg & $\mathbf{K}$ & $\mathrm{Na}$ & CEC & \multirow{2}{*}{ ESP\% } & \multirow{2}{*}{$\% C$} & \multirow{2}{*}{$\% 0 \mathrm{M}$} & \multirow{2}{*}{$\% \mathrm{~N}$} & \multirow{2}{*}{$\begin{array}{c}P \\
(\mathrm{mg} / \mathrm{kg})\end{array}$} & \multirow{2}{*}{ BS } \\
\hline & & & & & & & \multicolumn{5}{|c|}{ (Cmol/kg Soil) } & & & & & & \\
\hline Rice & 48 & 18.6 & 33.4 & Clay loam & 1.56 & 4.3 & 0.42 & 0.2074 & 0.15 & 0.48 & 1.255 & 38.25 & 0.1 & 0.17 & 0.01 & 4.38 & 58.78 \\
\hline Maize, Yam Cassava & 19.6 & 24.4 & 56.00 & Clay & 1.60 & 5.7 & 1.23 & 0.366 & 0.17 & 0.41 & 2.177 & 15.12 & 0.3 & 0.52 & 0.03 & 3.36 & 94.57 \\
\hline Agro-forestry & 40 & 26.8 & 33.2 & Clay loam & 1.10 & 4.7 & 0.88 & 0.173 & 0.16 & 0.35 & 1.564 & 22.38 & 2.8 & 4.81 & 0.20 & 5.1 & 69.39 \\
\hline Maize, Yam Cassava & 39 & 31.8 & 29.2 & Clay loam & 1.22 & 5.3 & 1.40 & 0.3675 & 0.145 & 0.145 & 2.057 & 7.05 & 2.01 & 3.46 & 0.20 & 5.44 & 93.42 \\
\hline Fallow & 29 & 358 & 36.00 & Clay loam & 1.35 & 5.2 & 0.15 & 0.2805 & 0.19 & 0.35 & 1.835 & 19.07 & 1.27 & 2.18 & 0.12 & 4.67 & 87.59 \\
\hline Rice & 31 & 34.2 & 34.8 & Clay loam & 1.50 & 4.6 & 1.44 & 0.517 & 0.18 & 0.18 & 2.317 & 7.77 & 1.26 & 2.17 & 0.13 & 5.02 & 46.61 \\
\hline Rice/sole Yam & 23 & 41.2 & 35.8 & Clay loam & 1.31 & 4.8 & 0.68 & 0.46 & 0.77 & 0.77 & 2.68 & 28.73 & 2.66 & 4.58 & 0.27 & 3.63 & 80.64 \\
\hline Yam, maize Cassava/Okra & 31 & 32.6 & 37.00 & Clay loam & 1.21 & 4.8 & 0.34 & 0.38 & 0.23 & 0.23 & 1.46 & 15.75 & 2.50 & 4.30 & 0.25 & 4.18 & 69.41 \\
\hline Fallow & 35 & 26.4 & 38.60 & Clay loam & 1.40 & 5.1 & 0.48 & 0.38 & 0.25 & 0.25 & 1.36 & 18.38 & 2.21 & 3.80 & 0.22 & 3.38 & 89.76 \\
\hline Cassava, Maize, Potato & 32 & 27.8 & 40.20 & Clay & 1.50 & 4.8 & 1.37 & 0.48 & 0.33 & 0.33 & 2.51 & 13.14 & 2.56 & 4.40 & 0.26 & 4.3 & 78.59 \\
\hline
\end{tabular}

$\mathrm{BD}=$ Bulk density, $\mathrm{CEC}=$ Cation exchange capacity, $\mathrm{BS}=$ Base saturation, $\mathrm{OM}=$ Organic matter.

Table 3. sub-surface physical and chemical properties of the soil from major cropping system in Ebonyin state.

\begin{tabular}{|c|c|c|c|c|c|c|c|c|c|c|c|c|c|c|c|c|c|c|}
\hline \multirow{2}{*}{ Location } & \multirow{2}{*}{$\begin{array}{l}\text { Landscape } \\
\text { position }\end{array}$} & \multirow{2}{*}{$\begin{array}{l}\text { Cropping } \\
\text { system }\end{array}$} & \multirow{2}{*}{$\begin{array}{c}\text { Sand } \\
(\%)\end{array}$} & \multirow{2}{*}{$\begin{array}{l}\text { Silt } \\
(\%)\end{array}$} & \multirow{2}{*}{$\begin{array}{l}\text { Clay } \\
(\%)\end{array}$} & \multirow{2}{*}{ Texture } & \multirow{2}{*}{ pH } & $\mathbf{C a}$ & Mg & $\mathbf{K}$ & $\mathrm{Na}$ & CEC & \multirow{2}{*}{$\begin{array}{l}\text { ESP } \\
(\%)\end{array}$} & \multirow{2}{*}{$\begin{array}{l}O C \\
(\%)\end{array}$} & \multirow{2}{*}{$\begin{array}{l}\text { OM } \\
\text { (\%) }\end{array}$} & \multirow{2}{*}{$\begin{array}{c}N \\
(\%)\end{array}$} & \multirow{2}{*}{$\begin{array}{c}P \\
\mathrm{mg} / \mathrm{kg}\end{array}$} & \multirow{2}{*}{$\begin{array}{l}\text { BS } \\
\text { (\%) }\end{array}$} \\
\hline & & & & & & & & \multicolumn{5}{|c|}{ (Cmol/kg Soil) } & & & & & & \\
\hline 1 & Upland & Mixed cropping & 46.4 & 30 & 23.6 & Clay loam & 4.9 & 1.84 & 0.38 & 0.4 & 0.15 & 2.76 & 5.43 & 0.05 & 0.09 & 0.01 & 3.36 & 82.21 \\
\hline 2 & Upland & Fallow & 34 & 20.8 & 45.2 & Clay & 4.1 & 0.68 & 0.27 & 0.68 & 0.24 & 1.85 & 12.96 & 2.14 & 3.68 & 0.21 & 2.76 & 65.68 \\
\hline 3 & Upland & Agro-forestry & 30 & 38.8 & 31.2 & Clay loam & 5.4 & 2.36 & 0.45 & 0.28 & 0.44 & 3.53 & 12.48 & 1.79 & 3.08 & 0.18 & 5.02 & 92.88 \\
\hline 4 & Midslope & Mixed cropping & 30 & 38.4 & 31.6 & Clay loam & 5.2 & 1.32 & 0.32 & 0.21 & 0.32 & 2.17 & 14.75 & 0.92 & 1.52 & 0.92 & 4.105 & 93.53 \\
\hline 5 & Lower/valley & Mono cropping & 34 & 9.2 & 56.8 & Clay & 4.5 & 1.41 & 0.062 & 0.15 & 0.15 & 1.77 & 8.48 & 1.9 & 3.27 & 1.9 & 5.1 & 69.32 \\
\hline
\end{tabular}

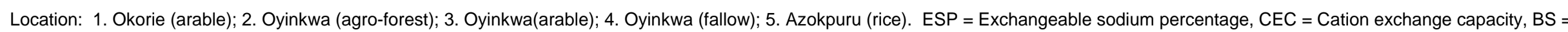
Base saturation, $\mathrm{OM}=$ Organic matter.

of improving soil fertility and crop productivity. Adequate use of fertilizers, appropriate tillage system (for example, plough across slopes) and minimum tillage on compacted soils should be encouraged to minimized erosion.

\section{Conclusion}

The results showed that cropping systems was the major contributing factor to soil degradation.

Major land degradation indicators that were identi- fied include improper crop combination and overcrowding of crops on heaps resulting in high competition for scarce soil resources and nutrient mining. Improper tillage system on the upland has resulted into soil loss. Poor yield of rice is attri- 
Table 4. Indicators and criteria for land degradation for selected soil parameters

\begin{tabular}{|c|c|c|c|c|c|c|c|}
\hline Location & Nitrogen & Phosphorus (P) & Potassium (K) & BS & ESP & Organic matter (OM) & BD $\mathrm{gcm}^{-3}$ \\
\hline 1 & 4 & 4 & 2 & 3 & 3 & 4 & 2 \\
\hline 2 & 4 & 4 & 1 & 2 & 2 & 4 & 2 \\
\hline 3 & 1 & 4 & 2 & 2 & 2 & 1 & 1 \\
\hline 4 & 4 & 4 & 1 & 2 & 1 & 1 & 1 \\
\hline 5 & 2 & 4 & 1 & 2 & 2 & 2 & 1 \\
\hline 6 & 2 & 4 & 1 & 3 & 1 & 2 & 2 \\
\hline 7 & 4 & 4 & 1 & 3 & 3 & 1 & 1 \\
\hline 8 & 4 & 4 & 3 & 3 & 2 & 1 & 1 \\
\hline 9 & 4 & 3 & 4 & 2 & 2 & 1 & 1 \\
\hline 10 & 3 & 4 & 4 & 3 & 2 & 1 & 2 \\
\hline
\end{tabular}

1 = None to slightly degraded, 2 = Moderately degraded, $3=$ Highly degraded soil, 4 = Very highly degraded spoil. FAO (1979), Snakin et al. (1996). ). ESP = ESP=Exchangeable sodium percentage, $B S=$ Base saturation, $B D=$ Bulk density.

Table 5. Scores for chemical and biological degradation of soils (Top soil).

\begin{tabular}{lcccc}
\hline \multirow{2}{*}{ Parameter } & \multicolumn{3}{c}{ Degradation Level } \\
\cline { 2 - 5 } & 1 & 2 & 3 & 4 \\
\hline Content of nitrogen \% & $>0.13$ & $0.10-0.13$ & $0.08-0.1$ & $<0.8$ \\
Content of P (mg/kg) & $>8$ & $7-8$ & $6-7$ & $<6$ \\
Content of ESP (Increase by \% of CEC) & $<10$ & $10-25$ & $25-50$ & $>50$ \\
BS (Decrease of saturation) $17>50 \%$ & $>2.5$ & $2.5-5$ & $5-10$ & $>.10$ \\
Organic Matter \% & $>2.5$ & $2-2.25$ & $1.0-2.0$ & $<1.0$ \\
Soil bulk density $\left(\mathrm{g} / \mathrm{cm}^{3}\right)$ & $<1.5$ & $1.5-2.5$ & $2.5-5$ & $>5$ \\
\hline
\end{tabular}

Locations 1. Okorie; valley bottom 2. Okorie; upland3. Oyinkwa; upland 4. Oyinkwa; upland upland 5. Oyinkwa; upland 6. Azokpuru; lowland /valley bottom 7. Abaomege; lowland /valley bottom 8. Abaomege; upland 9. Abaomege; fallow 10. Onu Ebonyin low land. ESP = Exchangeable sodium percentage, $B S=$ Base saturation), $C E C=$ Cation exchange capacity

buted to continuous cultivation of rice at the valley bottom with hydromorphic condition resulting to iron toxicity.

The government may play a crucial role by subsiding farm inputs and training of farmers through extension agents on good cropping and tillage systems. The major degradation issue in the area was low fertility while factors of land degradation include improper crop combination and impropertillage systems.

\section{REFERENCES}

Ande OT, Onajobi J (2009). Assessment of effects of controlled land use types on soil quality using inferential method. Afr. J. Biotechnol. 8(22):6267-6271.

Audebert A, Saahrawat KL (1996). Physiological adaptations to iron toxicity. Annual report 1995. Bouake, Cote d'Ivoire: WARDA. pp.5960.

Beinroth FH, Eswaran H, Reich PF, Van BE (1994). Land related stress in agro-ecosystem, In stresses in ecosystem and sustainable agriculture (ed.) S.M Virman, J.C Kayal; H Eswaran and I.R Abrol Oxford and Ibh, New Delhi pp.40-60.

Erickson JH, Dawfors B (1999). The effect of soil compaction on soil structure and crop. Bull. 354 Uppsala, Swedish institute of Agric. Engineering p.25.
Evenson RE, Gollin D (2003). Assessing The Impact of the Green Revolution, 1960 to 2000 . Science 300 (5620): pp. 758-762.

FAO, (Food and Agriculture Organization, (1979). A provisional method for land degradation assessment. FAO. Rome, $84 \mathrm{p}$.

Lal R (1994). Sustainable land use systems and soil resilience. In Greenland DJ, Szabolcs I (eds), Soil Resilience and Sustainable land use, CAB Int, Wallingford, UK, pp.41-68.

Mathias B, Folkard A (2005). Iron toxicity in rice- conditions and management concepts. J. plant Nutrit. Soil Sci. 168:558-573.

Michael AS, Niamh M (2000). Handbook for the Field Assessment of Land Degradation Overseas Development GroupUniversity of East AngliaNorwich, UK. pp. 97.

Nyathi Kimani SK, Jama P, Mapfumo, P, Murwira HK, Okalibo JK, Bationo A (2003). Soil fertility managmnet in semiarid area of East and Southern Africa $\mathrm{pp}=219-252$

Pagiola SJ, Bishop J, Landell-Mills N Eds, (2002). Selling forest environmental services land degradation. $p p=95-102$ Snakin VV, Krechetov PP, Kuzovnikova TA, Alyabina IO, Gurov AF, Stepichev AV (1996). The system of assessment of soil degradation. Soil Technol., 8: 331-343.

Walkley A, Black IA (1934). An examination of the Degtjareff method for determining soil organic matter and proposed modification of the chronic acid titration method. Soil Sci. 37: 29-38

Worden J, Reid R, Gichohi H (2003). Land use impacts on large wildlife and livestock in eth swamps o the greater Amboseli Ecosystem, Kajiado district, Kenya Lucid working paper series number 27 IIRI Nairobi Kenya. 